\title{
Typical Brazilian cheeses: safety, mineral content and adequacy to the nutritional labeling
}

\author{
Tayanna Bernardo Oliveira Nunes MESSIAS ${ }^{1}$, Marciane MAGNANI $^{2 *}$ (D), Tatiana Colombo PIMENTEL ${ }^{3}$, \\ Luana Martiniano da SILVA ${ }^{1}$, Juliane ALVES ${ }^{4}$, Tatiane Santi GADELHA ${ }^{4}$, Marcelo Antônio MORGANO \\ Maria Teresa Bertoldo PACHECO ${ }^{5}$, Maria Elieidy Gomes de OLIVEIRA ${ }^{1}$, \\ Rita de Cássia Ramos do Egypto QUEIROGA ${ }^{1} \dagger$
}

\begin{abstract}
This study aimed to evaluate the physicochemical and microbiological characteristics of six typical Brazilian cheeses (bovine milk coalho, goat milk coalho, fresh ricotta, manteiga, fresh Minas, and Padrão Minas). Padrão Minas cheese presented high acidity and the highest contents of protein, fat, and ash, while Ricotta cheese presented the lowest contents of protein, fat, and ash. Bovine milk coalho and Minas fresh cheeses were characterized as source of zinc. Manteiga cheese was characterized by the yellow color (higher $b^{*}$ values). Goat milk coalho cheese was characterized by the white color (higher $\mathrm{L}^{*}$ values) and presented the highest concentration of minerals (potassium, iron, magnesium, calcium, manganese, and phosphorus). Part of the typical Brazilian cheeses did not agree with the legislation for moisture (5.9\%) and fat in the dry matter (11.8\%) classifications, as well as, did not have adequate concentrations of protein (65.4\%) and fat (44.9\%) stated in the label, being the non-conformity dependent on the cheese type. Furthermore, 30\% of the cheeses (30\%) disagreed with the microbiological Brazilian legislation, as they presented coliforms and/or coagulase-positive Staphylococcus counts above the limits. It can be concluded that the Brazilian cheeses are nutritive, but the microbial quality and nutritional labels need improvement.
\end{abstract}

Keywords: curd cheese; butter cheese; microbial quality; legislation; mineral content; nutrition.

Practical Application: Cheeses are highly appreciated, and they provide essential nutrients for human nutrition.

\section{Introduction}

Cheeses are highly appreciated dairy products, and they provide essential nutrients for human nutrition in the form of proteins, bioactive peptides, amino acids, fat, fatty acids, vitamins, and minerals (Manuelian et al., 2017; Kamimura et al., 2019). A large variety of cheeses exist worldwide, which can be categorized based on several properties such as texture, milk employed (type and if the milk was pasteurized or not) and the manufacturing specificities, having broad ranges in composition and structural characteristics (Feeney et al., 2021).

In Brazil, cheese has socioeconomic and nutritional importance due to its significant commercialization and high consumption, playing an important role in the diet of population groups (Matera et al., 2018; Rolim et al., 2020).

The nutritional content provided by cheeses are important for health, and different types of cheeses can have different nutritional value (Feeney et al., 2021). Due to its various metabolic functions in the human body, determining mineral elements such as $\mathrm{Ca}, \mathrm{K}, \mathrm{Mg}, \mathrm{P}$ and $\mathrm{Na}$ and microelements such as $\mathrm{Fe}, \mathrm{Mn}$ and $\mathrm{Zn}$ in cheeses are of fundamental importance (Gharibzahedi \& Jafari, 2017). The use of an inductively coupled plasma optical emission spectrometer (ICP-OES) to determine minerals in cheese can help maintaining the quality of the manufacturing process and can contribute to quantify the majority and trace mineral elements (Matera et al., 2018).

Cheese can be contaminated through the milk utilized as well as in the processing steps if good manufacturing practices are not assured (Paramithiotis et al., 2017). The Brazilian legislation establish microbiological standard limits for cheeses through the absence of staphylococcal enterotoxins (ng/g) and Salmonella/25 g, counts up to $5 \times 10^{2} \mathrm{CFU}$ for staphylococci coagulase positive/g, and counts up $5 \times 10^{2}$ or $10^{3} \mathrm{CFU}$ to Escherichia coli/g depending the moisture contents (Brasil, 2019a). However, 1560 outbreaks were identified and related to Salmonella spp., 763 to Staphylococcus aureus and 533 to Escherichia

${ }^{1}$ Departmento de Nutrição, Universidade Federal da Paraíba - UFPB, João Pessoa, PB, Brasil

${ }^{2}$ Departmento de Engenharia de Alimentos, Universidade Federal da Paraíba - UFPB, João Pessoa, PB, Brasil

${ }^{3}$ Instituto Federal do Paraná, Campus Paranavaí, Paranavaí, PR, Brasil

${ }^{4}$ Departmento de Biologia Molecular, Universidade Federal da Paraíba - UFPB, João Pessoa, PB, Brasil

${ }^{5}$ Instituto de Tecnologia de Alimentos, Centro de Ciência e Qualidade de Alimentos, Universidade Estadual de Campinas - UNICAMP, São Paulo, SP, Brasil

*Corresponding author: magnani2@gmail.com

$\dagger$ Deceased: sadly, Prof Rita Queiroga died as a consequence of SARS-Covid-19 shortly before publication of this article, and after 30 years of dedicated research focused on dairy products. 
coli from 2000 to 2013 in Brazil. The importance of hygienicsanitary quality assessment is reinforced, since $183(7.8 \%)$ of the commercialized products involved in foodborne disease outbreaks in Brazil $(2,350)$ were milks and derivatives (Brasil, 2019), which is of concern to public health.

Coalho cheese has been produced in the Northeast of the country for more than 150 years, being one of the most common varieties of cheeses produced and marketed. Coalho is prepared by milk coagulation using rennet or other suitable coagulating enzymes, complemented or not by the action of selected lactic acid bacteria, and is usually commercialized within ten days of manufacture. Coalho is classified as a medium-to-high moisture cheese, with semi-cooked or traditionally cooked mass; fresh or ripened, and with fat in the dry matter (FDM) content ranging from 35 to $60 \%$ (Fontenele et al., 2017).

Manteiga cheese is produced by milk coagulation with the use of food grade organic acids and addition of a local product called "manteiga de garrafa" (butter-in-a-bottle, very similar to ghee, also known as "manteiga-da-terra" or "manteiga-do-sertão") (Kamimura et al., 2019). Ricotta cheese is a fresh cheese obtained by the precipitation of the whey proteins through acidification with citric acid associated with heat. It is classified as a very high or high moisture content cheese, non-ripened, and with a pH close to 6, presenting a limited shelf life (Rubel et al., 2019).

Minas fresh cheese is obtained by enzymatic coagulation of milk with rennet and/or other appropriate coagulant enzymes and is supplemented or not with the action of specific lactic acid bacteria. It is a non-ripened cheese, presents high moisture content, high $\mathrm{pH}$ values (5-6), and short shelf life (up to 21 days) (Nunes \& Caldas, 2017). Padrão Minas cheese is a ripened cheese with brittle texture and slightly acidic taste, which is manufactured using a starter culture composed of Lactococcus lactis ssp. cremoris and L. lactis ssp. lactis (Costa et al., 2019).

Only one study compared the nutritional value of typical Brazilian cheeses (Matera et al., 2018), but the microbial quality was not evaluated. In this sense, the objective of this study was to evaluate the physicochemical and microbiological characteristics of typical Brazilian cheeses (bovine milk coalho, goat milk coalho, fresh ricotta, manteiga, fresh Minas, and Padrão Minas).

\section{Materials and methods}

\subsection{Materials}

Different batches of different brands of 99 cheeses with great commercial representativeness were collected in the State of Paraíba, Brazil, of which three specimens were obtained from each batch, namely, bovine milk coalho cheese $(n=27)$, goat milk coalho cheese $(n=12)$, fresh ricotta $(n=21)$, manteiga cheese $(n=15)$, fresh Minas cheese $(n=12)$ and Padrão Minas cheese $(n=12)$. The samples were acquired respecting the batch turnover and expiration date, they contained the seal of the Federal Inspection Service (SIF), on the label and were vacuum packed. The cheeses were immediately packed in refrigeration $\left(4 \pm 2{ }^{\circ} \mathrm{C}\right)$ and analyzed.

\subsection{Physicochemical parameters and adequacy of nutritional labeling}

The chemical composition (moisture, protein, fat, and ash values) was determined according to Association of Official Analitical Chemists (2012). The fat in the dry matter (FDM) was calculated according to Association of Official Analitical Chemists (2012). The values obtained in $\mathrm{g} / 100 \mathrm{~g}$ were converted to $30 \mathrm{~g}$ portion and compared to the values declared on the labels.

Acidity in lactic acid by titration; hydrogenic potential $(\mathrm{pH})$ performed in a previously calibrated potentiometer; water activity, determined at $25^{\circ} \mathrm{C}$ using an AquaLab (model CX-2) and color instrumental determination in a Minolta colorimeter (model CR-300; Minolta Co., Osaka, Japan) according to the CIELAB system were also determined.

\subsection{Mineral quantification}

Mineral quantification was performed by ICP-OES (model 5100 VDV, Agilent Technologies ${ }^{\circ}$, Tokyo, Japan) with liquid argon gas with minimum purity of $99.996 \%$ (Air Liquide Brazil). The sample was prepared by dry digestion and analyzed for sodium, calcium, potassium, iron, phosphorus, magnesium, manganese, and zinc minerals (Association of Official Analitical Chemists, 2012). The samples were weighed in porcelain capsules containing $2 \mathrm{~g}$ of cheese, then pre-calculated on a heating plate and incinerated in a furnace muffle at $450{ }^{\circ} \mathrm{C}$ until ashes free of black spots were formed. The ashes were quantitatively transferred to a $25 \mathrm{~mL}$ volumetric flask after solubilization in $5 \%$ hydrochloric acid solution $(\mathrm{v} / \mathrm{v})$. The solution was filtered on quantitative filter paper before reading in the ICP-OES. The samples were diluted 10 more times for reading potassium.

The wavelengths $(\mathrm{nm})$ for each element were: calcium (317.93), magnesium (279.95), potassium (766.49), phosphorus (213.62), sodium (589.59), iron (259.94), manganese (257.61) and zinc (206.20). The analytical curves were prepared in 5\% $\mathrm{HCl}$ solution $(\mathrm{v} / \mathrm{v})$ from standard solutions at a concentration of $10.000 \mathrm{mg} / \mathrm{L}$ for $\mathrm{Na}, \mathrm{K}, \mathrm{P}, \mathrm{Mg}$ and $\mathrm{Ca}$ and $1.000 \mathrm{mg} / \mathrm{L}$ for $\mathrm{Mn}$ and Zn (Merck ${ }^{\circledR}$, Darmstadt, Germany). The concentration ranges for the preparation of the analytical curves were: 0.04 to $41 \mathrm{mg} / 100 \mathrm{~g}$ for $\mathrm{Na}$ and $\mathrm{Ca} ; 0.06$ to $61 \mathrm{mg} / 100 \mathrm{~g}$ for $\mathrm{P}$ and $\mathrm{K} ; 0.001$ to 1.000 for $\mathrm{Fe}, \mathrm{Mn}$ and $\mathrm{Zn}$; and 0.015 to $14.5 \mathrm{mg} / 100 \mathrm{~g}$ for $\mathrm{Mg}$.

Based on the results of the mineral content, the adequacy according to the Recommended Daily Intake for adults was calculated according to - RDC no. 269, of September 22, 2005 (Brasil, 2005), as well as the adequacy according to the portion of $30 \mathrm{~g}$ (Brasil, 2012, 2008).

\subsection{Microbiological evaluation}

The cheeses were evaluated following the established by the Brazilian Legislation. The thermotolerant coliform (coliforms at $45^{\circ} \mathrm{C}$ ), coagulase-positive Staphylococcus, E. coli and Salmonella spp. analyses were performed according to the procedures described by the American Public Health Association (2001). 


\subsection{Data analysis}

The analyses were performed in triplicated for each cheese. The results of the chemical composition, physicochemical analyses, and mineral content were expressed as mean and standard deviation. The data were submitted to Analysis of Variance (ANOVA) and Tukey test for comparison of the mean using the XLSTAT 2019.2 software (Adinsoft, Paris, France).

\section{Results and discussion}

\subsection{Physicochemical parameters and adequacy to legislation}

Table 1 presents the chemical composition of the typical Brazilian cheeses. The evaluated cheeses presented chemical composition in the range $(\mathrm{g} / 100 \mathrm{~g})$ : moisture (37-74), protein (12-28), fat (7-29), and ash (1.8-3.6). For a portion of $30 \mathrm{~g}$, the cheeses presented 4.65-7.62 g/100 g of protein; therefore, they could be considered a source of protein ( $>6$ g per portion) (Brasil, 2012), except ricotta cheese. The Brazilian cheeses presented different chemical composition $(\mathrm{p}<0.05)$. The ricotta cheese presented higher moisture content, and lower protein, fat and ash contents $(p<0.05)$ than the other cheeses.

Ricotta cheese is a non-pressed cheese and processed using whey as ingredient, resulting in a product with high moisture content, and, consequently, lower concentrations of fat, protein, and ash (Cereser et al., 2011). However, whey proteins are highly digestible, being rapidly absorbed by the body; therefore, they are considered of better nutritional quality than casein (Oliveira et al., 2012). It could be observed that the results of the chemical composition of ricotta cheese presented the highest standard deviation. This is associated to the lack of technical regulation for identity and quality of ricotta cheese in Brazil, leading to a lack of standardization for the product, which could impair the official quality control and compromise the food safety.
The Padrão Minas cheese had the lowest moisture content and, consequently, higher protein, fat, and ash contents ( $\mathrm{p}<0.05)$. During manufacture, this type of cheese is submitted to a pressing step, resulting in the decrease in the moisture content. Furthermore, it is a ripened cheese, and during the ripening process there is loss of moisture and concentration of the other components of the product (Bedoya-Serna et al., 2018).

Table 2 presents the physicochemical characteristics of the typical Brazilian cheeses. The cheeses presented $\mathrm{pH}$ of 5.86-7.02, acidity of $0.2-1.4 \%$ lactic acid, and Aw of 0.96-0.98. The Padrão Minas cheese and the fresh Ricotta presented the lowest $\mathrm{pH}$ values $(\mathrm{p}<0.05)$. For acidity, Padrão Minas cheese presented the highest value, while manteiga cheese presented the lowest value $(\mathrm{p}<0.05)$. Padrão Minas cheese is added with starter cultures; therefore, these cultures can use the lactose of the cheese, resulting in lactic acid production and $\mathrm{pH}$ reduction (Pereira et al., 2019). For the production of ricotta cheese, cheese whey is submitted to coagulation using citric acid $(0.11 \mathrm{~g} / \mathrm{L})$ and heating $\left(90^{\circ} \mathrm{C}\right.$ ) (Rubel et al., 2019), which can reduce the $\mathrm{pH}$ values of the cheeses. Although manteiga cheese is processed using organic acids (citric, acetic, or lactic), the curd is drained, washed, and melted with butter (Kamimura et al., 2019), which could result in lower acidity in the products.

The typical Brazilian cheeses presented light yellow color $\left(\mathrm{L}^{\star}=71.27\right.$ to $92.59, \mathrm{a}^{*}=-2.23$ to -3.71 , and $\mathrm{b}^{*}=11.78$ to 30.02$)$. The goat milk coalho cheese and the ricotta cheese presented the highest lightness and the lowest intensity of yellow $(\mathrm{p}<0.05)$, while manteiga cheese and Padrão Minas cheese presented the highest intensity of yellow color $(\mathrm{p}<0.05)$. Goat can transform all the dietary carotene into vitamin $\mathrm{A}$, therefore, products made with goat milk are characterized by a whiter color than products made with bovine milk (Ranadheera et al., 2019). The presence of whey proteins in ricotta cheese may have been responsible

Table 1. Chemical composition (g/100 g) of typical Brazilian cheese.

\begin{tabular}{|c|c|c|c|c|c|c|}
\hline \multicolumn{7}{|c|}{ Cheese } \\
\hline Variable $^{*}$ & $\begin{array}{c}\text { Cow milk coalho } \\
\text { cheese }\end{array}$ & $\begin{array}{c}\text { Goat milk coalho } \\
\text { cheese }\end{array}$ & Manteiga cheese & Minas fresh cheese & $\begin{array}{c}\text { Padrão Minas } \\
\text { cheese }\end{array}$ & Fresh ricotta \\
\hline Moisture & $45.42 \pm 4.49^{\mathrm{cd}}$ & $52.44 \pm 1.56^{\mathrm{b}}$ & $47.75 \pm 3.65^{c}$ & $43.91 \pm 5.52^{\mathrm{d}}$ & $41.58 \pm 0.43^{\mathrm{d}}$ & $64.70 \pm 6.08^{a}$ \\
\hline Protein & $24.17 \pm 2.63^{\mathrm{ab}}$ & $22.48 \pm 0.77^{b c}$ & $25.41 \pm 1.41^{\mathrm{a}}$ & $21.81 \pm 1.52^{\mathrm{c}}$ & $22.70 \pm 0.79^{a b c}$ & $15.49 \pm 4.52^{\mathrm{d}}$ \\
\hline Fat & $24.74 \pm 4.48^{\mathrm{a}}$ & $20.55 \pm 2.89^{b c}$ & $19.30 \pm 4.48^{c}$ & $24.13 \pm 2.64^{\mathrm{ab}}$ & $26.27 \pm 0.76^{\mathrm{a}}$ & $15.99 \pm 4.52^{\mathrm{d}}$ \\
\hline Ash & $3.58 \pm 0.91^{\mathrm{a}}$ & $3.59 \pm 0.22^{\mathrm{a}}$ & $2.48 \pm 0.39^{b}$ & $3.10 \pm 0.34^{\mathrm{ab}}$ & $3.61 \pm 0.24^{\mathrm{a}}$ & $1.78 \pm 0.98^{c}$ \\
\hline
\end{tabular}

Mean \pm standard deviation with different letters in the row means difference among cheeses $(\mathrm{p}<0.05)$; ${ }^{*}$ Values are expressed in $\mathrm{g} / 100 \mathrm{~g}$.

Table 2. Physicochemical characteristics of the typical Brazilian cheeses.

\begin{tabular}{|c|c|c|c|c|c|c|}
\hline \multicolumn{7}{|c|}{ Cheese } \\
\hline Variable & $\begin{array}{c}\text { Cow milk coalho } \\
\text { cheese }\end{array}$ & $\begin{array}{c}\text { Goat milk coalho } \\
\text { cheese }\end{array}$ & Manteiga cheese & Minas fresh cheese & $\begin{array}{c}\text { Padrão Minas } \\
\text { cheese }\end{array}$ & Fresh ricotta \\
\hline $\mathrm{pH}$ & $6.73 \pm 0.40^{\mathrm{a}}$ & $6.47 \pm 0.19^{\mathrm{ab}}$ & $6.50 \pm 0.46^{\mathrm{a}}$ & $6.75 \pm 0.53^{\mathrm{a}}$ & $6.08 \pm 0.04^{b}$ & $6.16 \pm 0.55^{b}$ \\
\hline Acidity ${ }^{1}$ & $0.55 \pm 0.03^{b}$ & $0.80 \pm 0.08^{\mathrm{ab}}$ & $0.26 \pm 0.01^{\mathrm{c}}$ & $0.74 \pm 0.04^{\mathrm{b}}$ & $1.18 \pm 0.02^{\mathrm{a}}$ & $0.66 \pm 0.04^{\mathrm{b}}$ \\
\hline Aw & $0.96 \pm 0.01^{c}$ & $0.97 \pm 0.01^{b}$ & $0.96 \pm 0.01^{\mathrm{c}}$ & $0.98 \pm 0.01^{\mathrm{ab}}$ & $0.96 \pm 0.01^{c}$ & $0.98 \pm 0.01^{\mathrm{a}}$ \\
\hline $\mathrm{L}^{*}$ & $87.12 \pm 2.80^{\mathrm{b}}$ & $92.59 \pm 8.75^{\mathrm{a}}$ & $71.27 \pm 5.12^{\mathrm{d}}$ & $86.54 \pm 4.94^{\mathrm{b}}$ & $81.86 \pm 1.18^{\mathrm{c}}$ & $92.33 \pm 1.27^{\mathrm{a}}$ \\
\hline$a^{*}$ & $-3.11 \pm 0.57^{\mathrm{a}}$ & $-2.99 \pm 0.50^{\mathrm{ab}}$ & $-3.71 \pm 2.40^{\mathrm{a}}$ & $-3.35 \pm 0.32^{\mathrm{a}}$ & $-3.09 \pm 0.18^{\mathrm{ab}}$ & $-2.23 \pm 0.28^{\mathrm{b}}$ \\
\hline$b^{*}$ & $23.23 \pm 3.75^{\mathrm{b}}$ & $11.78 \pm 1.40^{c}$ & $31.84 \pm 7.63^{\mathrm{a}}$ & $24.84 \pm 5.41^{\mathrm{b}}$ & $30.02 \pm 0.82^{\mathrm{a}}$ & $15.16 \pm 1.67^{c}$ \\
\hline
\end{tabular}

Mean \pm standard deviation with different letters in the row means difference among cheeses ( $\mathrm{p}<0.05)$; ${ }^{1}$ Acidity in $\%$ lactic acid. 
by the higher lightness. Manteiga cheese is added with butter, increasing the yellow color of the cheese (Kamimura et al., 2019). Proteolysis occurred during Padrão Minas cheese production and storage may have been associated to the color changes (Costa et al., 2017).

Table 3 presents the classification of the cheeses according the moisture content and FDM, and their compliance with the legislation. There is no Brazilian legislation for ricotta cheese and Padrão Minas cheese. Coalho cheese is characterized by a medium to high moisture content (36-54.9 g/100 g), and FDM of 35-60 g/100 g (Brasil, 1996). From the 9 brands of bovine milk coalho (A-I), only the G brand cheese was not suitable, being classified as extra fat cheese (with $60.24 \mathrm{~g} / 100 \mathrm{~g}$ fat). Therefore, $88.9 \%$ of the bovine coalho cheeses agreed with the legislation. The values observed for FDM in bovine coalho cheese in agreement with legislation are similar to those reported by Margalho et al. (2021) in a large survey of the gross composition of Brazilian artisanal. All the goat milk coalho cheeses followed the legislation.
Manteiga cheese must have a maximum moisture content of $54.9 \mathrm{~g} / 100 \mathrm{~g}$ and FDM varying from 25 to $55 \mathrm{~g} / 100 \mathrm{~g}$ (Brasil, 2001). Therefore, $100 \%$ of manteiga cheeses agreed with the legislation with results close to those previously reported for this type of cheese, also called "butter cheese" (Margalho et al., 2021). Minas Fresh cheese is classified as a very high moisture content cheese (> $55 \mathrm{~g} / 100 \mathrm{~g})$ and must present FDM varying from 25 and $44.9 \mathrm{~g} / 100 \mathrm{~g}$ (Brasil, 2004). Both brands of Minas fresh cheese evaluated presented lower moisture content (39.16 and $48.65 \mathrm{~g} / 100 \mathrm{~g}$ ), and the brand A also presented a higher FDM content $(46.68 \mathrm{~g} / 100 \mathrm{~g})$. Therefore, $100 \%$ of the Minas fresh cheeses did not agree with the legislation.

Figure 1 presents the adequacy of the cheeses comparing the chemical composition (protein and fat) presented in the label and that evaluated in the present study. According to the legislation (Brasil, 2003), the differences between the nutritional label and the experimental results must be lower than $20 \%$. For protein content, $33.33 \%$ of the bovine coalho cheese, $50 \%$ of the goat coalho cheese, $42.8 \%$ of the fresh ricotta, $20 \%$ of the manteiga

Table 3. Classification of the cheeses marketed in Brazil according to the Fat in the Dry Matter (FDM) and the moisture content (g/100 g).

\begin{tabular}{|c|c|c|c|c|c|c|}
\hline Cheese/Brand & $\begin{array}{l}\text { FDM content } \\
(\mathrm{g} / 100 \mathrm{~g})\end{array}$ & Classification & $\begin{array}{c}\text { Adequacy of FDM } \\
\text { content }^{1}\end{array}$ & $\begin{array}{l}\text { Moisture } \\
(\mathrm{g} / 100 \mathrm{~g})\end{array}$ & Classification & $\begin{array}{c}\text { Adequacy of } \\
\text { moisture }\end{array}$ \\
\hline \multicolumn{7}{|l|}{ Cow milk coalho cheese } \\
\hline A & $48.85 \pm 1.30$ & Fat & Suitable & $44.38 \pm 0.90$ & High & Suitable \\
\hline $\mathrm{C}$ & $35.71 \pm 3.52$ & Semi-fat & Suitable & $45.82 \pm 1.75$ & Average & Suitable \\
\hline $\mathrm{D}$ & $33.14 \pm 4.26$ & Semi-fat & Suitable & $48.68 \pm 2.59$ & High & Suitable \\
\hline G & $60.24 \pm 12.40$ & Extra fat & Non-compliance & $49.86 \pm 11.19$ & High & Suitable \\
\hline $\mathrm{H}$ & $42.58 \pm 1.56$ & Semi-fat & Suitable & $43.51 \pm .0 .77$ & Average & Suitable \\
\hline I & $45.65 \pm 1.94$ & Fat & Suitable & $42.17 \pm .0 .62$ & Average & Suitable \\
\hline \multicolumn{7}{|l|}{ Goat milk coalho cheese } \\
\hline $\mathrm{F}$ & $40.14 \pm 3.35$ & Semi-fat & Suitable & $52.88 \pm 1.60$ & High & Suitable \\
\hline $\mathrm{D}$ & $53.38 \pm 3.03$ & Fat & Not applicable $e^{*}$ & $54.32 \pm 3.76$ & High & Not applicable ${ }^{*}$ \\
\hline $\mathrm{E}$ & $39.90 \pm 7.44$ & Semi-fat & Not applicable $e^{*}$ & $60.58 \pm 0.64$ & Very high & Not applicable ${ }^{*}$ \\
\hline F & $56.34 \pm 4.60$ & Fat & Not applicable ${ }^{\star}$ & $67.18 \pm 1.91$ & Very high & Not applicable ${ }^{\star}$ \\
\hline $\mathrm{H}$ & $47.06 \pm 5.23$ & Fat & Not applicable ${ }^{*}$ & $64.39 \pm 0.71$ & Very high & Not applicable ${ }^{\star}$ \\
\hline I & $48.39 \pm 5.06$ & Fat & Not applicable & $68.51 \pm 0.90$ & Very high & Not applicable ${ }^{*}$ \\
\hline \multicolumn{7}{|l|}{ Manteiga cheese } \\
\hline $\mathrm{C}$ & $38.07 \pm 1.32$ & Semi-fat & Suitable & $50.55 \pm 1.53$ & High & Suitable \\
\hline $\mathrm{D}$ & $28.13 \pm 1.89$ & Semi-fat & Suitable & $47.57 \pm 1.28$ & High & Suitable \\
\hline $\mathrm{E}$ & $45.69 \pm 2.79$ & Fat & Suitable & $41.66 \pm 2.14$ & Average & Suitable \\
\hline $\mathrm{H}$ & $38.75 \pm 4.92$ & Semi-fat & Suitable & $47.67 \pm 0.49$ & High & Suitable \\
\hline
\end{tabular}


cheese, $100 \%$ of the Minas fresh cheese, and $0 \%$ of the Padrão Minas cheese were adequate. For fat content, $66.66 \%$ of the bovine coalho cheese, $50 \%$ of the goat coalho cheese, $85.7 \%$ of

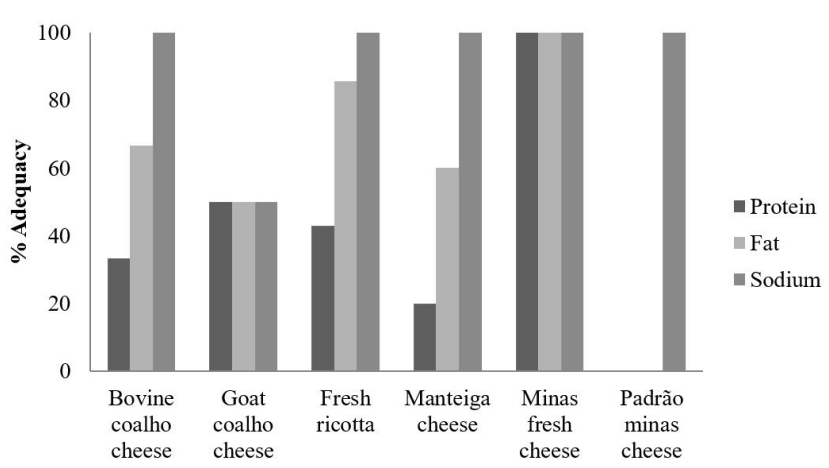

Figure 1. Comparison of cheese labels against the determined chemical composition according to the Brazilian legislation for labeling. the fresh ricotta, $60 \%$ of the manteiga cheese, $100 \%$ of the Minas fresh cheese, and $0 \%$ of the Padrão Minas cheese were adequate.

The results of the chemical composition and physicochemical characteristics indicate that Padrão Minas cheese has the highest nutritional value and acidity among the evaluated cheeses. Furthermore, it reported that many cheeses have chemical composition (protein and FDM) in disagreement with the legislation, as well, as, differences between the nutritional label and the experimental results higher than $20 \%$.

\subsection{Mineral content}

Table 4 presents the majority mineral content of the typical Brazilian cheeses and Table 5 presents the trace mineral content. Goat coalho cheese presented the highest concentration of potassium, iron, and magnesium, as well as, one of the highest concentrations of calcium, manganese, and phosphorus $(\mathrm{p}<0.05)$. In fact, goat milk presents higher amounts of $\mathrm{Ca}, \mathrm{P}, \mathrm{K}, \mathrm{Mg}$ and $\mathrm{Cl}$ compared to bovine milk (Ranadheera et al., 2019).

Table 4. Major mineral values $(\mathrm{mg} / 100 \mathrm{~g})$ in cheeses compared to the percentage of daily nutrient intake (RDI\%) and \% of daily nutrient intake per 30 g serving.

\begin{tabular}{|c|c|c|c|c|c|}
\hline Cheeses & Minerals & $\begin{array}{c}\text { Mean }( \pm \mathrm{DP}) \\
\mathrm{mg} / 100 \mathrm{~g}\end{array}$ & Values $\mathrm{RDI}^{*}$ & $\% \mathrm{RDI}$ & $\begin{array}{c}\text { \% RDI per serving } \\
(30 \mathrm{~g})\end{array}$ \\
\hline \multirow[t]{5}{*}{ Bovine milk coalho } & Calcium & $872.04 \pm 62.90^{\mathrm{a}}$ & $1000 \mathrm{mg}$ & 87.20 & 26.16 \\
\hline & Magnesium & $30.46 \pm 2.92^{\mathrm{b}}$ & $260 \mathrm{mg}$ & 11.72 & 3.51 \\
\hline & Phosphorus & $535.70 \pm 34.55^{\mathrm{a}}$ & $700 \mathrm{mg}$ & 76.53 & 22.96 \\
\hline & Potassium $(\mathrm{g})^{\star \star}$ & $86.19 \pm 17.46^{c}$ & $3.51 \mathrm{~g}$ & 245.58 & 73.68 \\
\hline & Sodium & $541.44 \pm 89.93^{\mathrm{b}}$ & $2400 \mathrm{mg}$ & 22.56 & 6.77 \\
\hline \multirow[t]{5}{*}{ Goat milk coalho } & Calcium & $932.03 \pm 62.61^{\mathrm{a}}$ & $1000 \mathrm{mg}$ & 93.20 & 27.96 \\
\hline & Magnesium & $48.54 \pm 10.39^{\mathrm{a}}$ & $260 \mathrm{mg}$ & 18.67 & 5.60 \\
\hline & Phosphorus & $595.60 \pm 20.99^{\mathrm{a}}$ & $700 \mathrm{mg}$ & 85.09 & 25.53 \\
\hline & Potassium $(\mathrm{g})^{\star \star}$ & $121.81 \pm 17.48^{\mathrm{a}}$ & $3.51 \mathrm{~g}$ & 347.01 & 104.10 \\
\hline & Sodium & $282.16 \pm 115.81^{\mathrm{c}}$ & $2400 \mathrm{mg}$ & 11.76 & 3.53 \\
\hline \multirow[t]{5}{*}{ Fresh ricotta } & Calcium & $932.03 \pm 293.32^{\mathrm{a}}$ & $1000 \mathrm{mg}$ & 93.20 & 27.96 \\
\hline & Magnesium & $18.67 \pm 5.40^{c}$ & $260 \mathrm{mg}$ & 7.18 & 2.15 \\
\hline & Phosphorus & $292.07 \pm 148.55^{\mathrm{b}}$ & $700 \mathrm{mg}$ & 41.72 & 12.52 \\
\hline & Potassium $(\mathrm{g})^{\star *}$ & $108.22 \pm 13.38^{\mathrm{ab}}$ & $3.51 \mathrm{~g}$ & 308.26 & 92.48 \\
\hline & Sodium & $82.28 \pm 38.29^{\mathrm{d}}$ & $2400 \mathrm{mg}$ & 3.43 & 1.03 \\
\hline \multirow[t]{5}{*}{ Manteiga cheese } & Calcium & $207.14 \pm 85.39^{c}$ & $1000 \mathrm{mg}$ & 20.71 & 6.21 \\
\hline & Magnesium & $10.89 \pm 4.67^{\mathrm{d}}$ & $260 \mathrm{mg}$ & 4.19 & 1.26 \\
\hline & Phosphorus & $275.70 \pm 37.47^{\mathrm{b}}$ & $700 \mathrm{mg}$ & 39.39 & 11.82 \\
\hline & Potassium $(\mathrm{g})^{\star *}$ & $76.61 \pm 30.32^{c}$ & $3.51 \mathrm{~g}$ & 218.23 & 65.47 \\
\hline & Sodium & $706.64 \pm 89.72^{\mathrm{a}}$ & $2400 \mathrm{mg}$ & 29.44 & 8.83 \\
\hline \multirow[t]{5}{*}{ Fresh minas } & Calcium & $840.10 \pm 51.80^{\mathrm{a}}$ & $1000 \mathrm{mg}$ & 84.01 & 25.20 \\
\hline & Magnesium & $29.89 \pm 3.05^{b}$ & $260 \mathrm{mg}$ & 11.50 & 3.45 \\
\hline & Phosphorus & $596.47 \pm 44.76^{\mathrm{a}}$ & $700 \mathrm{mg}$ & 85.21 & 25.56 \\
\hline & Potassium $(\mathrm{g})^{\star \star}$ & $84.97 \pm 4.78^{c}$ & $3.51 \mathrm{~g}$ & 242.17 & 72.65 \\
\hline & Sodium & $185.11 \pm 107.32^{\mathrm{c}}$ & $2400 \mathrm{mg}$ & 7.71 & 2.31 \\
\hline \multirow[t]{5}{*}{ Padrão minas } & Calcium & $800.05 \pm 45.45^{\mathrm{a}}$ & $1000 \mathrm{mg}$ & 80.01 & 24.00 \\
\hline & Magnesium & $31.97 \pm 2.87^{b}$ & $260 \mathrm{mg}$ & 12.30 & 3.69 \\
\hline & Phosphorus & $532.51 \pm 20.58^{\mathrm{a}}$ & $700 \mathrm{mg}$ & 76.07 & 22.82 \\
\hline & Potassium $(\mathrm{g})^{\star \star}$ & $87.07 \pm 8.66^{\mathrm{bc}}$ & $3.51 \mathrm{~g}$ & 248.15 & 74.44 \\
\hline & Sodium & $519.96 \pm 5.50^{\mathrm{b}}$ & $2400 \mathrm{mg}$ & 21.67 & 6.50 \\
\hline
\end{tabular}

Mean \pm standard deviation with different letters in the column means difference among cheeses for the same mineral $(\mathrm{p}<0.05) .{ }^{\star}$ Recommended Daily Intake for adults was calculated according to RDC no. 269, of September 22, 2005 (Brasil, 2005); ${ }^{* *}$ Reducing salt intake populations: report of a WHO forum and technical meeting (World Health Organization, 2013). 
Table 5. Trace mineral values $(\mathrm{mg} / 100 \mathrm{~g})$ in cheeses compared to the percentage of daily nutrient intake (RDI\%) and \% of daily nutrient intake per 30 g serving.

\begin{tabular}{|c|c|c|c|c|c|}
\hline Cheeses & Minerals & Mean $( \pm$ DP $) \mathrm{mg} / 100 \mathrm{~g}$ & Values RDI* & $\%$ RDI & $\begin{array}{c}\text { \% RDI per serving } \\
(30 \mathrm{~g})\end{array}$ \\
\hline \multirow[t]{2}{*}{ Bovine milk coalho } & Iron & $0.16 \pm 0.03$ & $14 \mathrm{mg}$ & 1.14 & 0.34 \\
\hline & Manganese & $0.03 \pm 0.00$ & $2.3 \mathrm{mg}$ & 1.30 & 0.39 \\
\hline \multirow[t]{2}{*}{ Goat milk coalho } & Iron & $0.26 \pm 0.01$ & $14 \mathrm{mg}$ & 1.86 & 0.56 \\
\hline & Manganese & $0.03 \pm 0.00$ & $2.3 \mathrm{mg}$ & 1.30 & 0.39 \\
\hline \multirow{2}{*}{ Fresh ricotta } & Manganese & $0.01 \pm 0.00$ & $2.3 \mathrm{mg}$ & 0.43 & 0.13 \\
\hline & Zinc & $0.72 \pm 0.20$ & $7 \mathrm{mg}$ & 10.29 & 3.09 \\
\hline \multirow[t]{3}{*}{ Manteiga cheese } & Iron & $0.15 \pm 0.07$ & $14 \mathrm{mg}$ & 1.07 & 0.32 \\
\hline & Manganese & $0.01 \pm 0.00$ & $2.3 \mathrm{mg}$ & 0.43 & 0.13 \\
\hline & Zinc & $2.31 \pm 0.38$ & $7 \mathrm{mg}$ & 33.00 & 9.90 \\
\hline \multirow{2}{*}{ Padrão minas } & Manganese & $0.02 \pm 0.00$ & $2.3 \mathrm{mg}$ & 0.87 & 0.26 \\
\hline & Zinc & $3.33 \pm 0.10$ & $7 \mathrm{mg}$ & 47.57 & 14.27 \\
\hline
\end{tabular}

${ }^{\star}$ Recommended Daily Intake for adults was calculated according to RDC no. 269, of September 22, 2005 (Brasil, 2005).

Manteiga cheese presented the lowest concentration of calcium, and magnesium, as well as one of the lowest concentrations of potassium, phosphorous, iron, manganese, and zinc $(\mathrm{p}<0.05)$. Manteiga cheese is processed using organic acids (citric, acetic, or lactic), and the curd is drained, washed, and melted with butter (Kamimura et al., 2019), which could result in loss of mineral content.

A product must provide at least $15 \%$ of the Recommended Daily Intake (RDI) per established portion to be considered a source of minerals (Brasil, 2012). The RDI values of the cheeses for magnesium were in the range of 1.26 to $5.60 \%$, therefore, they were not source of this mineral.

All cheeses could be considered sources of potassium, with RDI values between 65.47 and $104.10 \%$. Potassium is necessary for fluid balance, nerve transmission, muscle contraction and blood pressure maintenance (Gharibzahedi \& Jafari 2017). It is important to mention that the consumption of higher concentrations of potassium had no negative impact in health, and this mineral, in a form of $\mathrm{KCl}$, can be used to substitute sodium $(\mathrm{NaCl})$ in the manufacturing process of various cheeses.

Only manteiga cheese could not be considered a source of calcium (6.21\%), while the other cheeses presented $24-27.96 \%$ of the RDI. Calcium is the basic structural element of bones and teeth. It is also considered an element with a wide range of physiological functions, being responsible for normal cardiac function, hormonal secretion, blood coagulation, cell membrane permeability, and activation of various enzymes (Silva et al., 2018). Bovine coalho cheese, goat milk coalho cheese, fresh Minas cheese, and Padrão Minas cheese presented RDI values of 22.82-25.56\% for phosphorus, therefore, they could be considered sources of this mineral. Phosphorus is a component in body cells, being necessary for maintaining homeostasis and energy production (Gharibzahedi \& Jafari, 2017).

Considering the trace minerals, bovine milk coalho and fresh Minas cheese could be considered a source of zinc. Zinc is necessary for protein and genetic material production participating in normal fetal development and in the health system (Gharibzahedi \& Jafari, 2017). Iron and manganese were not present in significant levels in all the analyzed cheeses, being less than $4 \%$ of the RDI.

Cheeses are classified as low-salt (<120 mg/100 g), moderate-sodium (120-400 mg/100 g), and high-sodium (> $400 \mathrm{mg} / 100 \mathrm{~g}$ ) (Matera et al., 2018). The sodium content found, in a general view, was high in manteiga cheese $(706.7 \mathrm{mg} / 100 \mathrm{~g})$, bovine milk coalho cheese $(541.44 \mathrm{mg} / 100 \mathrm{~g})$, and Padrão Minas cheese $(520.00 \mathrm{mg} / 100 \mathrm{~g})$; moderate in goat milk coalho (282.15 mg/100 g), and fresh Minas cheese (185.12 mg/100 g), and low in fresh ricotta $(82.28 \mathrm{mg} / 100 \mathrm{~g})$.

Considering the salt content based on the brands (Figure 2), all the manteiga and Padrão Minas cheeses had high sodium content (> $400 \mathrm{mg} / 100 \mathrm{~g}$ ). Of the total bovine coalho cheese, approximately $89 \%$ had high sodium contents and $11 \%$ had moderate sodium contents. The fresh ricotta and Minas fresh cheeses were classified as low-sodium, as $72 \%$ of the fresh ricotta and $50 \%$ of the Minas fresh cheeses had less than $120 \mathrm{mg}$ of sodium per $100 \mathrm{~g}$ of cheese. Regarding goat coalho cheese, $100 \%$ of the samples were characterized by moderate sodium content.

High sodium consumption has been a major concern for public health (Li et al., 2017). Cheese has been highlighted as a target food for salt reduction (World Health Organization, 2013), and this reduction has recently received considerable media attention after a report on the high salt content of a wide range of 


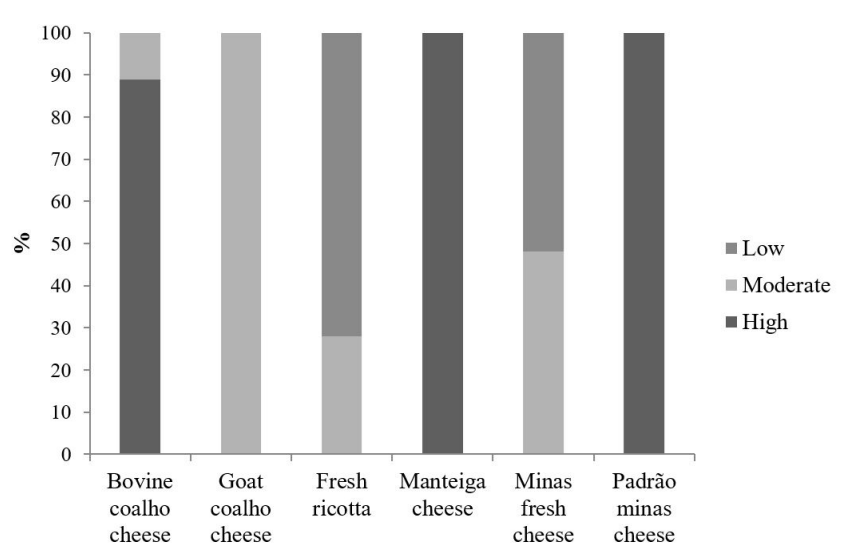

Figure 2. Classification of the cheeses (\% of cheeses) based on the sodium content. Low-salt $(<120 \mathrm{mg} / 100 \mathrm{~g})$, moderate-sodium (120-400 mg/100 g), and high-sodium (> $400 \mathrm{mg} / 100 \mathrm{~g})$.

cheeses in supermarkets in the United Kingdom (Hashem et al., 2014). The Brazilian Ministry of Health has determined that 16 products should reduce their sodium contents by 2020 , including different types of cheeses. However, in Brazil, there are still few studies on sodium reduction in cheeses (Matera et al., 2018). It is important to mention, however, that the cheeses of the present study would provide only $1.03-8.83 \%$ of the daily sodium consumption in a $30 \mathrm{~g}$ portion.

For sodium content, $100 \%$ of the nutritional labels of the bovine coalho cheese, fresh ricotta, manteiga cheese, Minas fresh cheese, and Padrão Minas cheese were in agreement with the experimental results (Figure 1), while this was observed only in $50 \%$ of the goat milk coalho samples. The results of the mineral content indicate that goat milk coalho cheese has the highest mineral content among the evaluated cheeses. Furthermore, it reported that typical Brazilian cheeses are, in a general view, sources of potassium, phosphorous and calcium, but present low concentrations of iron and manganese. Although some types of cheeses have a high sodium concentration, the contribution to the RDI is not of concern (1-8\%).

\subsection{Microbiological evaluation}

The legislation allows maximum counts of coliforms at $45^{\circ} \mathrm{C}$ of $10^{3} \mathrm{for}$ medium-moisture cheeses, $5 \times 10^{3}$ for high-moisture cheeses, and $5 \times 10^{2}$ for very high-moisture cheeses (Brasil, 2019a). Non-conformity was observed in $30.77 \%$ of the 78 cheeses analyzed, distributed in the following proportions among the cheeses: 11 bovine milk coalho cheese, 3 ricotta cheese, 3 goat milk coalho cheese; 1 manteiga cheese, and 6 Minas fresh cheeses. All Padrão Minas cheese presented suitable coliforms counts. Therefore, $0 \%$ of Padrão Minas cheese, $40.74 \%$ of the bovine milk coalho cheese, $60 \%$ of the goat milk coalho cheese, $6.66 \%$ of the manteiga cheese, and $100 \%$ of the Minas fresh cheese presented higher coliforms counts than the allowed by legislation. The higher stability of the Padrão Minas cheese may be associated to the lower moisture content (Table 1), higher salt content (Table 4), the antagonistic effect of the starter culture, and the ripening step.
E. coli was detected in $11.54 \%$ of the cheeses ( 9 out 78 cheeses). The positive results were distributed in 5 samples of bovine milk coalho cheese, 3 samples of fresh ricotta cheese, and 1 sample of Minas fresh cheese. E. coli was not found in the goat milk coalho cheese, manteiga cheese or Padrão Minas cheese. E. coli is a good indicator of the hygienic-sanitary quality of food. Therefore, cheese samples with $E$. coli can be considered unfit for consumption (Haller et al., 2009). Brazilian legislation does not specify the maximum concentrations of this microorganism in cheeses.

The legislation allows maximum counts of coagulase-positive Staphylococcus of $10^{3}$ for medium-moisture cheeses, $10^{3}$ for high-moisture cheeses, and $5 \times 10^{2}$ for very high-moisture cheeses (Brasil, 2019b). Coagulase-positive Staphylococcus was identified in 5 samples of cheeses (6.41\%); however, only 1 bovine milk coalho cheese, and 1 Minas Fresh cheese presented counts higher than the allowed by legislation. Therefore, 3.70\% of the bovine milk coalho cheese, and $16.67 \%$ of the Minas Fresh cheese presented higher coagulase-positive Staphylococcus counts than the allowed by legislation. The legislation does not allow the presence of Salmonella spp. in $25 \mathrm{~g}$ of the cheese samples. Salmonella spp. was not detected in any of the analyzed samples.

The non-compliance with the legislation of many cheeses indicate a lack of hygienic-sanitary quality of the raw material used in the cheese production and/or non-compliance with good manufacturing practices, which enables possible transmission of pathogenic microorganisms through this food product and represents a major public health risk to consumers. This study demonstrated the need for improvements in the cheese production process. Thus, new studies aimed at identifying the contamination points in the production chain of the analyzed cheeses need to be conducted. This analysis will provide data concerning the origin of bacterial contamination, which is essential for more efficient control and prevention of foodborne diseases.

\section{Conclusion}

This study evaluated the physicochemical and microbiological characteristics of typical Brazilian cheeses (bovine milk coalho, goat milk coalho, fresh ricotta, manteiga, fresh Minas, and Padrão Minas). Padrão Minas cheese presented great nutritional value, high acidity and goat milk coalho cheese presented the highest concentration of minerals (potassium, iron, magnesium, calcium, manganese, and phosphorus). Part of the typical Brazilian cheeses did not agree with the legislation for moisture (5.9\%) and FDM (11.8\%) classifications, as well as, did not have adequate concentrations of protein (65.4\%) and fat (44.9\%) stated in the label, being the non-conformity dependent on the cheese type. Furthermore, part of the cheeses (>30\%) disagreed with the microbiological legislation, as they presented more coliforms and/or coagulase-positive Staphylococcus than the allowed. It can be concluded that the Brazilian cheeses are nutritive, but the microbial quality and nutritional labels need improvement.

\section{Acknowledgements}

This study was financed, in part, by the Coordenação de Aperfeiçoamento de Pessoal de Nível Superior - Brasil (CAPES) 
- Finance Code 001 and Conselho Nacional de Desenvolvimento Científico e Tecnologico - Brasil (CNPq).

\section{References}

American Public Health Association - APHA. (2001). Compendium of methods for the microbiological examination of foods (4th ed.). Washington, DC: APHA.

Association of Official Analitical Chemists - AOAC. (2012). Official methods of analysis of AOAC International (19th ed.). Gaithersburg: AOAC.

Bedoya-Serna, C. M., Dacanal, G. C., Fernandes, A. M., \& Pinho, S. C. (2018). Antifungal activity of nanoemulsions encapsulating oregano (Origanum vulgare) essential oil: in vitro study and application in Minas Padrão cheese. Brazilian Journal of Microbiology, 49(4), 929935. http://dx.doi.org/10.1016/j.bjm.2018.05.004. PMid:30145265.

Brasil, Ministério da Agricultura do Abastecimento e da Reforma Agrária. (1996). Aprova os regulamentos técnicos de identidade e qualidade de produtos lácteos (Portaria n 146, de 7 de março de 1996). Diário Oficial [da] República Federativa do Brasil.

Brasil, Ministério da Agricultura do Abastecimento e da Reforma Agrária. (2001). Regulamentos técnicos de identidade e qualidade de manteiga da terra ou manteiga de garrafa; queijo de coalho e queijo de manteiga (Instrução Normativa no 30 DE 26 de junho de 2001). Diário Oficial [da] República Federativa do Brasil.

Brasil, Agência Nacional de Vigilância Sanitária - ANVISA. (2003, December 23). Dispõe sobre regulamento técnico sobre rotulagem nutricional de alimentos embalados (Resolução RDC n 360, de 23 de dezembro de 2003). Diário Oficial [da] República Federativa do Brasil.

Brasil, Ministério da Agricultura do Abastecimento e da Reforma Agrária. (2004). Regulamento técnico para fixação de identidade e qualidade de queijo minas frescal (Instrução Normativa nº 04, de 01 de março de 2004). Diário Oficial [da] República Federativa do Brasil.

Brasil, Agência Nacional de Vigilância Sanitária - ANVISA. (2005, September 22). O regulamento técnico sobre a Ingestão Diária Recomendada (IDR) de proteína, vitaminas e minerais (Resolução RDC n 269, de 22 de setembro de 2005). Diário Oficial [da] República Federativa do Brasil.

Brasil, Ministério da Saúde. (2008). Guia Alimentar para a população brasileira: promovendo a alimentação saudável. Brasília, DF: Ministério da Saúde.

Brasil, Agência Nacional de Vigilância Sanitária - ANVISA. (2012, November 12). Dispõe sobre regulamento técnico sobre informação nutricional complementar (Resolução RDC no 54 de 12 de novembro de 2012). Diário Oficial [da] República Federativa do Brasil.

Brasil, Ministério da Saúde. (2019). Surtos de Doenças Transmitidas por Alimentos no Brasil Informe 2018. Secretaria de Vigilância em Saúde, Departamento de Vigilância Epidemiológica, Coordenação Geral de Doenças Transmissíveis, Vigilância Epidemiológica das Doenças Transmitidas por Alimentos. Retrieved from https://portalarquivos2. saude.gov.br/images/pdf/2019/fevereiro/15/Apresenta----o-SurtosDTA---Fevereiro-2019.pdf.

Brasil, Agência Nacional de Vigilância Sanitária - ANVISA. (2019a, December 23). Estabelece os padrões microbiológicos de alimentos e sua aplicação (Resolução RDC n 331, de 23 de dezembro de 2019). Diário Oficial [da] República Federativa do Brasil.

Brasil, Agência Nacional de Vigilância Sanitária - ANVISA. (2019b, December 23). Estabelece as listas de padrões microbiológicos para alimentos prontos para oferta ao consumidor (Instrução normativa $n^{\circ}$ 60, de 23 de dezembro de 2019). Diário Oficial [da] República Federativa do Brasil.
Cereser, N. D., Rossi, O. D. Jr., Marchi, P. G. F., Souza, V., Cardoso, M. V., \& Martineli, T. M. (2011). Avaliação da qualidade microbiológica da ricota comercializada em supermercados do estado de São Paulo. Ciência Animal Brasileira, 12(1), 149-155. http://dx.doi.org/10.5216/ cab.v12i1.6372.

Costa, K. K. F. D., Soares, M. S. Jr., Rosa, S. I. R., Caliari, M., \& Pimentel, T. C. (2017). Changes of probiotic fermented drink obtained from soy and rice byproducts during cold storage. $L W T, 78,23-30$. http:// dx.doi.org/10.1016/j.lwt.2016.12.017.

Costa, R. G. B., Caiafa, A. Jr., Cruz, A. G., Sobral, D., Costa, L. C. G. Jr., Paula, J. C. J., Moreira, G. M. M., \& Teodoro, V. A. M. (2019). Effect of partial replacement of sodium chloride with potassium chloride on the characteristics of Minas Padrão cheese. International Dairy Journal, 91, 48-54. http://dx.doi.org/10.1016/j.idairyj.2018.12.002.

Feeney, E. L., Lamichhane, P., \& Sheehan, J. J. (2021). The cheese matrix: understanding the impact of cheese structure on aspects of cardiovascular health - a food science and a human nutrition perspective. International Journal of Dairy Technology, 0, 1-15.

Fontenele, M. A., Bastos, M. S. R., Santos, K. M. O., Bemquerer, M. P., \& Egito, A. S. (2017). Peptide profile of coalho cheese: a contribution for Protected Designation of Origin (PDO). Food Chemistry, 219, 382-390. http://dx.doi.org/10.1016/j.foodchem.2016.09.171. PMid:27765241.

Gharibzahedi, S. M. T., \& Jafari, S. M. (2017). The importance of minerals in human nutrition: bioavailability, food fortification, processing effects and nanoencapsulation. Trends in Food Science \& Technology, 62, 119-132. http://dx.doi.org/10.1016/j.tifs.2017.02.017.

Haller, L., Poté, J., Loizeau, J., \& Wildi, W. (2009). Distribution and survival of faecal indicator bacteria in the sediments of the Bay of Vidy. Ecological Indicators, 9(3), 540-547. http://dx.doi.org/10.1016/j. ecolind.2008.08.001.

Hashem, K. M., He, F. J., Jenner, K. H., \& MacGregor, G. A. (2014). Cross-sectional survey of salt content in cheese: a major contributor to salt intake in the UK. BMJ Open, 4(8), e005051. http://dx.doi. org/10.1136/bmjopen-2014-005051. PMid:25099933.

Kamimura, B. A., Magnani, M., Luciano, W. A., Campagnollo, F. B., Pimentel, T. C., Alvarenga, V. O., Pelegrino, B. O., Cruz, A. G., \& Sant'Ana, A. S. (2019). Brazilian artisanal cheeses: an overview of their characteristics, main types and regulatory aspects. Comprehensive Reviews in Food Science and Food Safety, 18(5), 1636-1657. http:// dx.doi.org/10.1111/1541-4337.12486. PMid:33336917.

Li, Y., Berenson, J., Moran, A. E., \& Pagán, J. A. (2017). Who does not reduce their sodium intake despite being advised to do so? A population segmentation analysis. Preventive Medicine, 99, 77-79. http://dx.doi.org/10.1016/j.ypmed.2017.01.017. PMid:28189807.

Manuelian, C. L., Currò, S., Penasa, M., Cassandro, M., \& De Marchi, M. (2017). Characterization of major and trace minerals, fatty acid composition, and cholesterol content of Protected Designation of Origin cheeses. Journal of Dairy Science, 100(5), 3384-3395. http:// dx.doi.org/10.3168/jds.2016-12059. PMid:28237598.

Margalho, L. P., Kamimura, B. A., Pimentel, T. C., Balthazar, C. F., Araujo, J. V. A., Silva, R., Conte-Junior, C. A., Raices, R. S. L., Cruz, A. G., \& Sant'Ana, A. S. (2021). A large survey of the fatty acid profile and gross composition of Brazilian artisanal cheeses. Journal of Food Composition and Analysis, 101, 103955. http://dx.doi.org/10.1016/j. jfca.2021.103955.

Matera, J., Luna, A. S., Batista, D. B., Pimentel, T. C., Moraes, J., Kamimura, B. A., Ferreira, M. V. S., Silva, H. L. A., Mathias, S. P., Esmerino, E. A., Freitas, M. Q., Raices, R. S. L., Quitério, S. L., Sant’Ana, A. S., Silva, M. C., \& Cruz, A. G. (2018). Brazilian cheeses: a survey covering physicochemical characteristics, mineral content, fatty acid profile 
and volatile compounds. Food Research International, 108, 18-26. http://dx.doi.org/10.1016/j.foodres.2018.03.014. PMid:29735047.

Nunes, M. M., \& Caldas, E. D. (2017). Preliminary quantitative microbial risk assessment for Staphylococcus enterotoxins in fresh Minas cheese, a popular food in Brazil. Food Control, 73(B), 524-531. http://dx.doi. org/10.1016/j.foodcont.2016.08.046.

Oliveira, M. E. G., Garcia, E. F., Queiroga, R. C. R. E., \& Souza, E. L. (2012). Technological, physicochemical and sensory characteristics of a Brazilian semi-hard goat cheese (coalho) with added probiotic lactic acid bacteria. Scientia Agrícola, 69(6), 370-379. http://dx.doi. org/10.1590/S0103-90162012000600005.

Paramithiotis, S., Drosinos, E. H., \& Skandamis, P. N. (2017). Food recalls and warnings due to the presence of foodborne pathogens - a focus on fresh fruits, vegetables, dairy and eggs. Current Opinion in Food Science, 18, 71-75. http://dx.doi.org/10.1016/j.cofs.2017.11.007.

Pereira, J. P. F., Mageste, A. C., Campos, N. D. S., Sousa, R. A. D., Francisquini, J. D. A., Perrone, I. T., Carvalho, A. F., Nunes, R. M., Martins, M. F., \& Silva, P. H. F. (2019). Calcium partition in Minas Padrão cheese and its bioaccessibility during ripening time. Food Science and Technology, 39(4), 859-866. http://dx.doi.org/10.1590/ fst. 12518 .
Ranadheera, C. S., Evans, C. A., Baines, S. K., Balthazar, C. F., Cruz, A. G., Esmerino, E. A., Freitas, M. Q., Pimentel, T. C., Wittwer, A. E., Naumovski, N., Graça, J. S., Sant'Ana, A. S., Ajlouni, S., \& Vasiljevic, T. (2019). Probiotics in goat milk products: delivery capacity and ability to improve sensory attributes. Comprehensive Reviews in Food Science and Food Safety, 18(4), 867-882. http:// dx.doi.org/10.1111/1541-4337.12447. PMid:33337004.

Rolim, F. R. L., Freitas, O. C. No., Oliveira, M. E. G., Oliveira, C. J. B., \& Queiroga, R. C. R. E. (2020). Cheeses as food matrixes for probiotics: In vitro and in vivo tests. Trends in Food Science \& Technology, 100, 138-154. http://dx.doi.org/10.1016/j.tifs.2020.04.008.

Rubel, I. A., Iraporda, C., Gallo, A., Manrique, G. D., \& Genovese, D. B. (2019). Spreadable ricotta cheese with hydrocolloids: effect on physicochemical and rheological properties. International Dairy Journal, 94, 7-15. http://dx.doi.org/10.1016/j.idairyj.2019.03.002.

Silva, H. L. A., Balthazar, C. F., Rocha, R. S., Moraes, J., Esmerino, E. A., Silva, M. C., Raices, R. S. L., Pimentel, T. C., Freitas, M. Q., \& Cruz, A. G. (2018). Sodium reduction and flavor enhancers addition: is there an impact on the availability of minerals from probiotic Prato cheese? LWT, 93, 287-292. http://dx.doi.org/10.1016/j.lwt.2018.03.053.

World Health Organization - WHO. (2013). Mapping salt reduction Initiatives in the WHO European region. Copenhagen: WHO Regional Office for Europe. 